\title{
Market Integration: An Application of Co-integration and Error Correction Model to Rice Markets in Bangladesh
}

\author{
M A B Siddique, S. K Raha ${ }^{1}$ and M Shahe Alam ${ }^{*}$ \\ Agricultural Economics Division, Bangladesh Rice Research Institute, Gazipur-1701, Bangladesh ${ }^{1}$ Dept. of \\ Cooperation and Marketing, Bangladesh Agricultural University, Mymensingh, Bangladesh \\ *Corresponding author:msalam@_07@yahoo.com
}

\begin{abstract}
The study was conducted to investigate the degree and nature of spatial integration among district level monthly wholesale price of rice in Northwestern and greater Mymensingh region of Bangladesh. Market integration was examined by co-integration method-while price fluctuations were estimated by Error Correction Mechanism (ECM). Stationarity of data was checked with the help of Augmented Dickey-Fuller (ADF) ('tau') test. Unit root test indicated that all the price series were non-stationary at level (original form of data), but were stationary after first difference. Engle Granger integration test indicated that all of the pair wise coefficients of price series were greater than the critical value at $1 \%$ level of significance implying strong and close proximity of inter regional price linkage, attributed to good communication, better infrastructural facilities etc. Therefore, wholesale price of paddy/rice at the regional level were spatially integrated in the long run even though rice markets were geographically dispersed. The extent of degree of integration demonstrated strong association (as all the coefficients were significant at $1 \%$ level), which is an indicator of efficient, and competitive marketing system, ultimately ensured maximum returns to the producers as well as expected reasonable price of the consumers. Though Law of One Price (LOP) was not effective between any market pairs, yet price signals reached the relevant sources appropriately. The distance between markets as a causal factor did not appear to be an impediment to efficient/inefficient adjustment of price to new information.
\end{abstract}

Keywords: Spatial integration, co-integration, error correction mechanism, unit root test, first difference

\section{Introduction}

Scientific methods and various new strategy of farming system have tremendously increased the production level of agriculture. With the diversified economic characteristics, regional specialization in production of agricultural commodities is inevitable and if the producers produced different crops according to their specialization, they would be more benefited. Based on the theory of comparative advantage, such regional specialization would result in optimum resource use and overall higher production. Nevertheless, such regional specialization would require the establishment of appropriate trade linkage between deficit and surplus areas of production. If the perfect flow of information takes place between the regions; it will be helpful for the producers and consumers to take right decision at right time, which would finally uplift the speed of the economy as a whole. Thus, the trade linkage would be more effective if the markets or regions are closely integrated.

Spatial market integration refers to a situation in which arbitrage causes prices in different markets to move together and where price signals and other related information are 
transmitted smoothly across the markets (Ghosh, 2000). The basic idea underlying the concept of market integration is to understand the interaction among prices of spatially separated markets. In a competitive marketing system with free flow of information, the price differences between the two markets will be equal to or less than the transportation costs between the two markets.

In the past, market integration was tested by using bivariate correlation or 'static' model (Gilbert, 1969, Illori, 1968, Cummings, 1967, Lele, 1967, Jones, 1972, Gupta, 1973) and later on by Ravallion's (1986) 'dynamic' model. But all of the earlier version contained methodological flaws which showed spurious relationship and inefficient estimation. To overcome those problems, Polaskas and HarrisWhite (1993) proposed a new method based on Engle Granger's (1987) co-integration test. Recent advancement in time series analysis especially those related to co-integration and error correction mechanism have lead to an explosion in testing food market integration (Asche et.al.1999, Blauch,1997, Goletti et al. 1995) in world wide.

The basic idea behind co-integration is very simple. For example, $\mathrm{Y}_{\mathrm{t} 1}$ and $\mathrm{Y}_{\mathrm{t} 2}$ are two nonstationary variables in their levels but become stationary after differencing, say once. Obviously, any relationship obtained between the two variables by the method of regression which may arise specifically due to nonstationarity of the variables may be spurious. However, if it can be established that there exists some linear combination of the variables such that it is stationary, then these linear combination will evidently describe an equilibrium relationship in the sense that $\mathrm{Y}_{\mathrm{t} 1}$ and $\mathrm{Y}_{\mathrm{t} 2}$ can not wander away indefinitely from the equilibrium position and must revert back to the equilibrium position, although individually each of the variables can drift away indefinitely from any starting point. Economically, two variables will be co-integrated if they have a long-term or equilibrium relationship between them (Gujarati, 2003).

However, studies related to market integration are very scanty in Bangladesh. The present study has therefore; been undertaken to explore the nature and extent of rice market integration of Bangladesh with the help of latest developed cointegration method.

The overall objective of the study was to evaluate empirically the extent and nature of spatial market integration of wholesale price of rice in different regions of Bangladesh. However, the specific objectives were:

(1) To measure the degree of integration among the different markets

(2) To examine if the 'Law of One Price' (LOP) exists between the markets or not?

(3) To determine the speed of adjustment of prices between the markets.

(4) To analyse the eventual implication of the existing level of rice market integration.

\section{Methodology}

The study was conducted based on time series information of rice price from January 1994 to December 2004 of Dhaka, Mymensingh, Sherpur, Kishoregonj, Bogra, Rangpur and Dinajpur. District level monthly whole sale rice price (120 observations for each district) was collected from Directorate of Agricultural Marketing (DAM). To measure market integration the following regression model was employed:

$\mathrm{P}_{\mathrm{it}}=\alpha+\beta \mathrm{P}_{\mathrm{jt}}+\varepsilon_{\mathrm{t}}$

Where, $\mathrm{P}_{\mathrm{i}}$ and $\mathrm{P}_{\mathrm{j}}$ are price series of a specific commodity in two markets $\mathrm{i}$ and $\mathrm{j}$, $\mathrm{t}$ is time and $\varepsilon_{\mathrm{t}}$ is the residual term assumed to be distributed identically and independently. Since $P_{i t}$ and $P_{j t}$ are integrated of order one, i.e., I(1), their linear combination is also I(1) or stationary. Therefore, their residuals will be stationary $\mathrm{I}(0)$. The parameter $\alpha$ represents domestic transportation costs, processing costs, sales tax etc. The Engle Granger (1987) co-integration is based on 
residuals i.e., $\varepsilon_{\mathrm{t}}=\mathrm{P}_{\mathrm{it}}-\beta \mathrm{P}_{\mathrm{jt}}$. The test of market integration is straightforward, if $P_{i}$ and $P_{j}$ are stationary variables (Baharumshah and Habibullah, 1994).

Often, however, economic variables are nonstationary in which case the conventional test is biased to reject the null hypothesis. Therefore, it is necessary to check the level of stationary before proceeding furthermore. Chinn (1991) suggests several steps to analyzing time-series data. A time series is said to be stationary if its mean, variance and covariance exists and they are invariant to time t. On the other hand, a nonstationary time series possesses a characteristic that is a function of time t. However, a nonstationary time series can be transformed into a stationary, by differencing between the values of the two successive periods. A necessary condition of co-integration method is that the order of the variables must be same. A time series is said to be integrated of order d, if it becomes a stationary series after differencing $\mathrm{d}$ times (Engle and Granger, 1987).

\subsection{Stationarity}

Stationarity of a time series is very essential as the use of a non stationary time series in regression analysis can give rise to dubious and spurious relationships. Stationary series is defined as one, whose parameter that describe the series (namely the mean, variance and autocorrelation) is independent of time or rather exhibit constant mean and variance and have autocorrelation that is invariant through time. Stationarity of the variables will be checked with the help of unit root test.

\subsection{Unit root and cointegration test}

The unit root test was performed following the procedure:

$\mathrm{P}_{\mathrm{t}}=\mathrm{Pt}_{\mathrm{I}}+\mathrm{u}_{\mathrm{t}}$

where $u_{t}$ is the stochastic error term that follows the classical assumptions. Equation (2) is a first order autoregressive process and to find out the unit root problem the value of $\mathrm{P}$ at time $\mathrm{t}$ was regressed on its value at time $t-1$. If the coefficient of $\mathrm{P}_{\mathrm{t}-1}$ was in fact equal to one, that is known as unit root problem.

i,e $\mathrm{P}_{\mathrm{t}}=\rho \mathrm{P}_{\mathrm{t}-\mathrm{I}}+\mathrm{u}_{\mathrm{t}} \quad-1 \leq \mathrm{p} \leq 1$

where, $\rho=1$ then the stochastic variable $P_{t}$ has a unit root.

To detect the 'unit root' of the variables, DF (Dickey-Fuller) test was employed which is known as $\tau$ (tau) test in the literature of time series. The test statistics is simply the $t$ statistics; however, under the null hypothesis it is not distributed as student-t but the ratio can be compared with critical values tabulated in Fuller (1976). Again, in case of correlated $u_{t}$, DickeyFuller has developed another test which is known as the Augmented Dickey-Fuller (ADF) test. The ADF test consists of estimating the following regression:

$\Delta \mathrm{P}_{\mathrm{t}}=\beta_{1}+\beta_{2} \mathrm{t}+\delta \mathrm{P}_{\mathrm{t}-1}+\alpha_{\mathrm{i}} \sum_{i+1}^{m} \Delta \mathrm{P}_{\mathrm{t}-1}+\varepsilon_{\mathrm{t}} \ldots$ (4)

where $\varepsilon_{t}$ is a pure white noise error term and where $\Delta \mathrm{P}_{\mathrm{t}-1}=\left(\mathrm{P}_{\mathrm{t}-1}-\mathrm{P}_{\mathrm{t}-2}\right), \Delta \mathrm{P}_{\mathrm{t}-2}=\left(\mathrm{P}_{\mathrm{t}-2}-\mathrm{P}_{\mathrm{t}-3}\right)$, etc. ADF test statistic has the same asymptotic distribution as the DF statistics, so the same critical value can be used (Gujarati, 2003).

After determining the non-stationary level of the variables then there may be potentiality of cointegrating relationship between them. To test the co-integration, null hypothesis $\left(\mathrm{H}_{\mathrm{o}}: \eta=0\right)$ will be tested against the alternative $\left(\mathrm{H}_{1}: \eta<0\right)$. The null hypothesis will be rejected if estimated $\phi$ is negative and found to be significantly different from zero.

Comparing the equations (1) and (4), equation (4) represents a 'strong-form' test of market integration, where under the null hypothesis, parameter $\alpha$ should be equal to zero, while $\beta$ should be equal to one. On the other hand, if $\alpha$ $\neq 0$ and $\beta=1$, than the 'weak-form' test of market integration persists (Zainas, 1993, Polaskas Harris-White, 1993). According to Engle-Granger (1987), model specified by equation (4) does not make any sense unless $\mathrm{P}_{\mathrm{i}}$ 
and $\mathrm{P}_{\mathrm{j}}$ are of same order of integration. Thus, a necessary condition for $\mathrm{P}_{i}$ and $\mathrm{P}_{j}$ to be cointegrated is that they must be integrated of the same order. Testing whether the variables are cointegrated is simply another unit root test on the residual of equation of (1). The test involved regressing the first difference of the residual series on lagged level and level (original) dependent variable is as follows;

$$
\Delta \varepsilon=\phi \varepsilon_{\mathrm{t}-1+\sum_{t=1}^{m}} \theta_{\mathrm{k}} \Delta \varepsilon_{\mathrm{t}-\mathrm{k}}+\nu_{t}
$$

Again the statistic is the $t$ statistic of $\phi$. The critical values are tabulated in Fuller (1976).

\section{Results and Discussion}

\subsection{Unit root test of rice price series}

Market integration was measured by 'cointegration' technique which was developed by Engle-Granger and Error-Correction Mechanism (ECM). Co-integration was tested by pair wise of seven locations of the study area simultaneously to determine whether there exists any long run relationship between them or not. Co-integration theory states that although two or more variables may be non-stationary in their level, but there may exist some linear combination of them which are stationary. Instinctively, this implies that individual variables exhibit some explosive pattern over time. However, when the price differential is considered, the explosive pattern disappeared and acquired the tendency of return to some 'equilibrium' value (i.e., the mean).

The results of the ADF test of seven wholesale price series of Dhaka,Sherpur, Mymensingh, Kishoregonj, Bogra, Rangpur and Dinajpur are presented in Table 1 . It is observed that testing the null hypothesis of non-stationary against an alternative of stationary, the results of ADF test statistics at levels cannot be rejected, even at 10 per cent levels. But at first difference, all of the price series showed their stationarity. Therefore, it suggests that null of the no co-integration can be rejected, and the alternative is accepted for all price series. So it can be inferred that all the price data were stationary after first differences.

Table 1: Unit root test of wholesale price series

\begin{tabular}{|c|c|c|c|c|}
\hline \multirow{2}{*}{ Markets } & \multicolumn{2}{|c|}{ Levels } & \multicolumn{2}{|c|}{ First difference } \\
\hline & $\begin{array}{l}\text { Augmented Dickey } \\
\text { Fuller (ADF) test }\end{array}$ & P-Values & $\begin{array}{l}\text { Augmented Dickey } \\
\text { Fuller (ADF) test }\end{array}$ & P-Values \\
\hline Dhaka & -1.641 & 0.103 & -9.445 & .000 \\
\hline Sherpur & -1.212 & 0.228 & -7.382 & .000 \\
\hline Kishoregonj & -1.810 & 0.730 & -7.379 & .000 \\
\hline Mymensingh & -1.445 & 0.151 & -6.645 & .000 \\
\hline Bogra & -2.414 & 0.710 & -7.904 & .000 \\
\hline Rangpur & -0.540 & 0.590 & -8.598 & .000 \\
\hline Dinajpur & -1.961 & 0.052 & -9.882 & .000 \\
\hline
\end{tabular}

Critical values at $1 \%$ level is 3.78 
Table 2: Pair wise co-integration, Engle-Granger (tau) tests for monthly average wholesale price series of different markets (1990-2004)

\begin{tabular}{lccccccc}
\hline \multicolumn{1}{c}{ Markets } & Dhaka & $\begin{array}{c}\text { Sher } \\
\text { pur }\end{array}$ & $\begin{array}{c}\text { Kiskore } \\
\text { gon }\end{array}$ & $\begin{array}{c}\text { Mymen } \\
\text { singh }\end{array}$ & Bogra & Rangpur & Dinajpur \\
& & -4.362 & -4.789 & -4.083 & -3.532 & -4.594 & -5.874 \\
Dhaka & - & - & -3.668 & -4.532 & -3.700 & -3.977 & -4.594 \\
Sherpur & - & - & - & -3.552 & -3.700 & -4.143 & -3.825 \\
Kiskoregonj & - & - & - & - & -4.049 & -4.335 & -3.983 \\
Mymensingh & - & - & - & - & - & -4.397 & -4.076 \\
Bogra & - & - & - & - & - & - & -6.055 \\
Rangpur & - & - & - & - & - & - & - \\
Dinajpur & - & - & - & &
\end{tabular}

Note: Critical value with lags at 1 per cent level is -3.51

Critical value with lags at 5 per cent level is -2.89

Critical value with lags at 10 per cent level is -2.58

\subsection{Test of co-integration}

After having established that the price series are in fact first difference stationary, the next step is to test the co-integration among them. The test for co-integration is the Engle-Granger (tau) test and error correction mechanism (ECM).

All possible pair wise combination of the price series was chosen. The test statistics is given in Table 2. It is revealed that all the coefficients of pair wise markets are seen to be greater than the critical value at 1 per cent level of significance. Therefore, null hypothesis of no integration is rejected for all the selected markets.

Therefore, all the markets pair like DhakaSherpur, Dhaka-Kiskoregonj, DhakaMymensingh, Dhaka-Bogra, Dhaka-Rangpur, Dhaka- Dhaka- Dinajpur, Sherpur- KiskoregonjMymensingh, Sherpur-Bogra, Sherpur-Rangpur, Sherpur-Dinajpur, Kiskoregonj-Mymensingh, Kiskoregonj-Bogra, Kiskoregonj- Rangpur, Kiskoregonj- Dinajpur, Mymensingh-Bogra, Mymensingh-Rangpur etc are co-integrated in terms of wholesale price. The empirical results implied that the price series are co-integrated and there is a stable equilibrium relationship between them, that is, all the market is spatially integrated. However, this situation prevailed in the markets while prices are tied together in the long run, but it may drift apart in the short-run because of scarceness of availability of information and lack of quicker dissemination of available information.

To test the restriction $\beta=1$ and $\alpha=0$, that is to test the validity of 'strong' form ofintegration, it would be sufficient to test the relationship of $\mathrm{p}_{\text {it }}$ $=\alpha+p_{\mathrm{jt}}+\mathrm{u}_{\mathrm{t}}$ for co-integration, where the term $\alpha=0$, absorbs the influence of a number of factors like transportation costs, processing costs and sales taxes etc. If there hold LOP, the difference, $\mathrm{z}_{\mathrm{t}}=\mathrm{p}_{\mathrm{it}}-\mathrm{p}_{\mathrm{jt}}$ will be $\mathrm{I}(1)$ or first differenced, in which case the co-integration test becomes a unit root test of a univariate case [testing whether or not $\mathrm{z}_{\mathrm{t}}$ is an $\mathrm{I}(1)$ variable]. Rejection of the no cointegration hypothesis shows that the imposed restriction is a valid co-integrating vector which makes the regression of $p_{i t}$ on $p_{j t}$ non spurious and implies a complete pass-through of price changes in the long-run (Zainas,1993). 
Table 3: Testing for strong $(\alpha=0, \beta=1)$ form of integration

\begin{tabular}{|c|c|c|}
\hline Market pairs & $\begin{array}{l}\text { t-value } \\
\text { for } \alpha=0\end{array}$ & $\begin{array}{l}\mathrm{t} \text {-value } \\
\text { for } \beta=1\end{array}$ \\
\hline Dhaka- Sherpur & $\begin{array}{l}3.279 \\
(0.001)\end{array}$ & $\begin{array}{l}4.520 \\
(0.000)\end{array}$ \\
\hline Dhaka- Kishoregonj & $\begin{array}{l}3.325 \\
(0.001)\end{array}$ & $\begin{array}{l}2.405 \\
(0.018)\end{array}$ \\
\hline Dhaka- Mymensingh & $\begin{array}{l}3.695 \\
(0.000)\end{array}$ & $\begin{array}{l}1.784 \\
(0.077)\end{array}$ \\
\hline Dhaka- Bogra & $\begin{array}{l}3.476 \\
(0.001)\end{array}$ & $\begin{array}{l}5.426 \\
(0.000)\end{array}$ \\
\hline Dhaka- Rangpur & $\begin{array}{l}4.321 \\
(0.000)\end{array}$ & $\begin{array}{l}-0.001 \\
(0.999)\end{array}$ \\
\hline Dhaka- Dinajpur & $\begin{array}{l}4.423 \\
(0.000)\end{array}$ & $\begin{array}{l}0.389 \\
(0.698)\end{array}$ \\
\hline Sherpur- Kishoregonj & $\begin{array}{l}2.783 \\
(0.006)\end{array}$ & $\begin{array}{l}1.434 \\
(0.154)\end{array}$ \\
\hline Sherpur- Mymensingh & $\begin{array}{l}3.718 \\
(0.000)\end{array}$ & $\begin{array}{l}-0.848 \\
(0.398)\end{array}$ \\
\hline Sherpur- Bogra & $\begin{array}{l}2.924 \\
(0.004)\end{array}$ & $\begin{array}{l}2.529 \\
(0.013)\end{array}$ \\
\hline Sherpur- Rangpur & $\begin{array}{l}3.071 \\
(0.003)\end{array}$ & $\begin{array}{l}1.266 \\
(0.208)\end{array}$ \\
\hline Sherpur- Dinajpur & $\begin{array}{l}3.483 \\
(0.001)\end{array}$ & $\begin{array}{l}0.369 \\
(0.713)\end{array}$ \\
\hline Kishoregonj- Mymensingh & $\begin{array}{l}4.753 \\
(0.000)\end{array}$ & $\begin{array}{l}-0.509 \\
(0.612)\end{array}$ \\
\hline Kishoregonj- Bogra & $\begin{array}{l}4.614 \\
(0.000)\end{array}$ & $\begin{array}{l}-0.154 \\
(0878)\end{array}$ \\
\hline Kishoregonj- Rangpur & $\begin{array}{l}4.785 \\
(0.000)\end{array}$ & $\begin{array}{l}-0.916 \\
(0.361)\end{array}$ \\
\hline Kishoregonj-Dinajpur & $\begin{array}{l}4.874 \\
(0.000)\end{array}$ & $\begin{array}{l}-1.009 \\
(0.315)\end{array}$ \\
\hline Mymensingh - Bogra & $\begin{array}{l}4.008 \\
(0.000)\end{array}$ & $\begin{array}{l}1.852 \\
(0.066)\end{array}$ \\
\hline Mymensingh- Rangpur & $\begin{array}{l}4.377 \\
(0.000)\end{array}$ & $\begin{array}{l}-0.314 \\
(0.754)\end{array}$ \\
\hline Bogra- Rangpur & $\begin{array}{l}3.129 \\
(0.002)\end{array}$ & $\begin{array}{l}-0.916 \\
(0.361)\end{array}$ \\
\hline Bogra- Dinajpur & $\begin{array}{l}2.956 \\
(0.004)\end{array}$ & $\begin{array}{l}-0.086 \\
(0.931)\end{array}$ \\
\hline Rangpur- Dinajpur & $\begin{array}{l}2.956 \\
(0.004)\end{array}$ & $\begin{array}{l}-0.086 \\
(0.931)\end{array}$ \\
\hline
\end{tabular}

Figure in the parenthesis indicate level of significance 
Table 4: Results of Error Correction Mechanism $\left(\Delta \mathrm{p}_{1}=\alpha+\beta \Delta \mathrm{p}_{2}+\gamma \quad \mathrm{u}_{\mathrm{t}-1}\right)$

\begin{tabular}{|c|c|c|c|c|c|}
\hline \multicolumn{2}{|c|}{$\begin{array}{l}\text { Markets/Dependent } \\
\text { variable }\left(\Delta \mathrm{p}_{1}\right)\end{array}$} & $\begin{array}{c}\text { Constant } \\
(\alpha)\end{array}$ & \multicolumn{2}{|c|}{ Independent variable $\left(\Delta \mathrm{p}_{2}\right)$} & \multirow{2}{*}{$\begin{array}{c}\mathrm{U}_{\mathrm{t}-1} \\
\\
0.188 \\
(-4.044)\end{array}$} \\
\hline$\Delta$ Dhaka & $=$ & $\begin{array}{l}5.772 \\
(3.243)\end{array}+$ & $\begin{array}{r}\Delta \text { Sherpur } 0.403 \\
(5.809)\end{array}$ & - & \\
\hline$\Delta$ Dhaka & $=$ & $\begin{array}{l}6.028+ \\
(2.956)\end{array}$ & $\begin{array}{c}\Delta \text { Kishoregonj } 0.333 \\
(3.620)\end{array}$ & - & $\begin{array}{c}0.147 \\
(-2495)\end{array}$ \\
\hline$\Delta$ Dhaka & $=$ & $\begin{array}{l}7.347 \\
(3.821)\end{array}+$ & $\begin{array}{c}\Delta \text { Mymensingh } 0.167 \\
(1.876)\end{array}$ & - & $\begin{array}{c}0.120 \\
(-2.926)\end{array}$ \\
\hline$\Delta$ Dhaka & $=$ & $\begin{array}{l}6.377+ \\
(3.551)\end{array}$ & $\begin{array}{c}\Delta \text { Bogra } 0.376 \\
(5.925)\end{array}$ & - & $\begin{array}{c}0.051 \\
(-2.051)\end{array}$ \\
\hline$\Delta$ Dhaka & $=$ & $\begin{array}{l}7.233+ \\
(3.097)\end{array}+$ & $\begin{array}{c}\Delta \text { Rangpur } 0.233 \\
(1.388)\end{array}$ & - & $\begin{array}{c}0.138 \\
(-3.070)\end{array}$ \\
\hline$\Delta$ Dhaka & $=$ & $\begin{array}{l}10.154 \\
(5.057)\end{array}+$ & $\begin{array}{c}\Delta \text { Dinajpur } 0.096 \\
(1.021)\end{array}$ & - & $\begin{array}{c}0.100 \\
(-3.758)\end{array}$ \\
\hline$\Delta$ Sherpur & $=$ & $\begin{array}{l}5.343 \\
(2.348)\end{array}+$ & $\begin{array}{c}\Delta \text { Kishoregonj } 0.317 \\
(3.157)\end{array}$ & - & $\begin{array}{c}0.165 \\
(-3.382)\end{array}$ \\
\hline$\Delta$ Sherpur & $=$ & $\begin{array}{l}8.434 \\
(3.730)\end{array}+$ & $\begin{array}{c}\Delta \text { Mymensingh } 0.014 \\
(0.128)\end{array}$ & - & $\begin{array}{c}0.202 \\
(-3.406)\end{array}$ \\
\hline$\Delta$ Sherpur & $=$ & $\begin{array}{l}6.554+ \\
(2.970)\end{array}$ & $\begin{array}{r}\Delta \text { Bogra } 0.237 \\
(2.977)\end{array}$ & - & $\begin{array}{c}0.043 \\
(1.535)\end{array}$ \\
\hline$\Delta$ Sherpur & $=$ & $\begin{array}{l}5.730+ \\
(2.213)\end{array}$ & $\begin{array}{c}\Delta \text { Rangpur } 0.317 \\
(1.709)\end{array}$ & - & $\begin{array}{c}0.172 \\
(-3.581)\end{array}$ \\
\hline$\Delta$ Sherpur & $=$ & $\begin{array}{l}8.880+ \\
(3.848)\end{array}$ & $\begin{array}{c}\Delta \text { Dinajpur } 0.107 \\
(3.228)\end{array}$ & - & $\begin{array}{c}0.043 \\
(-3.033)\end{array}$ \\
\hline$\Delta$ Kishoregc & $\mathrm{nj}=$ & $\begin{array}{l}9.565+ \\
(4.870)\end{array}$ & $\begin{array}{c}\Delta \text { Mymensingh } 0.018 \\
(0.184)\end{array}$ & & $\begin{array}{c}0.137 \\
(-3.820)\end{array}$ \\
\hline$\Delta$ Kishoregc & $n j=$ & $\begin{array}{l}9.565+ \\
(4.644)\end{array}$ & $\begin{array}{r}\Delta \text { Bogra } 0.021 \\
(0.298)\end{array}$ & & $\begin{array}{c}0.054 \\
(-2.491)\end{array}$ \\
\hline$\Delta$ Kishoregc & $\mathrm{nj}=$ & $\begin{array}{l}5.422 \\
(2.422)\end{array}+$ & $\begin{array}{c}\Delta \text { Rangpur } 0.467 \\
(2.916)\end{array}$ & - & $\begin{array}{c}0.145 \\
(-3.325)\end{array}$ \\
\hline$\Delta$ Kishoregc & $\mathrm{nj}=$ & $\begin{array}{l}9.920+ \\
(4.923)\end{array}$ & $\begin{array}{c}\Delta \text { Dinajpur } 0 . .063 \\
(0.645)\end{array}$ & - & $\begin{array}{c}0.084 \\
(-3.179)\end{array}$ \\
\hline$\Delta$ Mymensir & $\mathrm{gh}=$ & $\begin{array}{l}6.775+ \\
(3.183)\end{array}$ & $\begin{array}{r}\Delta \text { Bogra } 0.150 \\
(0.987)\end{array}$ & - & $\begin{array}{c}0.015 \\
(-1.261)\end{array}$ \\
\hline$\Delta$ Mymensir & $\mathrm{gh}=$ & $\begin{array}{l}6.641+ \\
(2.525)\end{array}$ & $\begin{array}{c}\Delta \text { Rangpur } 0.122 \\
(0.962)\end{array}$ & - & $\begin{array}{c}0.054 \\
(-1.734)\end{array}$ \\
\hline$\Delta$ Bogra & $=$ & $\begin{array}{l}7.058+ \\
(3.860)\end{array}$ & $\begin{array}{c}\Delta \text { Rangpur } 0.174 \\
(2.663)\end{array}$ & - & $\begin{array}{c}0.104 \\
(-1.128)\end{array}$ \\
\hline$\Delta$ Bogra & $=$ & $\begin{array}{l}8.916+ \\
(3.995)\end{array}$ & $\begin{array}{c}\Delta \text { Dinajpur } 0.066 \\
(2.196)\end{array}$ & - & $\begin{array}{c}0.109 \\
(-1.607)\end{array}$ \\
\hline$\Delta$ Rangpur & $=$ & $\begin{array}{l}6.052+ \\
(3.331)\end{array}$ & $\begin{array}{c}\Delta \text { Dinajpur } 0.289 \\
(3.271)\end{array}$ & - & $\begin{array}{c}0.189 \\
(-3.828)\end{array}$ \\
\hline
\end{tabular}

Figures in the parenthesis are t- values. 
Table 5: Speed of adjustment (short-run equilibrium) of wholesale prices among selected market pairs.

\begin{tabular}{lccccccc}
\hline Markets & Dhaka & Sherpur & Kishoregon & Mymensingh & Bogra & Rangpur & Dinajpur \\
\hline Dhaka & - & 18.8 & 14.7 & 20.2 & 13.8 & 5.1 & 1.0 \\
Sherpur & - & - & 12.0 & 16.5 & 13.7 & 4.3 & 3.2 \\
Kishoregonj & - & - & - & 17.2 & 13.2 & 14.5 & 8.4 \\
Mymensingh & - & - & - & - & 15.0 & 5.4 & 1.5 \\
Bogra & - & - & - & - & - & 10.4 & 10.9 \\
Rangpur & - & - & - & - & - & - & 18.9 \\
Dinajpur & - & - & - & - & - & - & - \\
\hline
\end{tabular}

\subsection{Law of one price}

It is revealed from the analysis (Table 3) that the strong form of pair wise market integration of wholesale markets was not there (present) as the restriction $\alpha=0$ and $\beta=1$ showed the level of significance positive for all markets pairs. So, the null hypothesis could not be rejected for at all any market pairs and 'Law of One Price' is not effective between any market pairs in the study area. However, the restriction $\beta=1$, is rarely satisfied in the real situation. On the other hand, if $\beta=1$ and $\alpha \neq 0$, there is weak form of cointegration. In most applications, the 'weak form' test for market integration is usually tested in empirical analysis.

\subsection{Error correction model (ecm)}

It is revealed from the Table 4 that the coefficients of error term were negative and statistically significant for the wholesale rice markets in the study districts, implying that there exists short-run dynamics with long-run equilibrium.

This implies that if any divergence from longrun equilibrium occurs in period $\mathrm{t}-1$, it will be adjusted towards equilibrium level in period $t$.

\subsection{Speed of adjustment}

Table .5 shows the speed of adjustment of different rice markets toward equilibrium position. It ranges from 10 to 20 percent. The highest speed of adjustment was observed between the wholesale price of Dhaka and Mymensingh (20\%) and lowest was for Dhaka and Dinajpur (10\%).

It implies that if any divergence appears from the equilibrium it will be adjusted toward the equilibrium level between Dhaka and Mymensingh in $(30 / 0.20=1.5) 1.5$ days and that of Dhaka and Dinajpur in $(30 / 0.10=3) 3$ days.

\section{Conclusions}

The results indicated that the wholesale price series are non-stationary in levels but are stationary at first difference which necessitated the use of an error correction model. Results of cointegration test indicated that the wholesale price of paddy/rice in the regional (districts) level was spatially integrated in the long run, even they were geographically dispersed, although price transmission was found to be lacking in the short run. The degree of market integration demonstrated that the rice markets in the study area were competitive and efficient in wholesale level, which indicated that the price signals reached the relevant sources timely but 'Law of One Price' was not effective between any market pairs in the study area. The distances between markets were not an impediment to efficient adjustment of price to new information. Therefore, in order to maximize the farmer's return, they should adjust on market information and choose the most advantageous market in time and space when they marketed their product. 


\section{References}

Asche, F., Bremnes, H. and Wessells, C. R. 1999. Product Aggregation, Market Integration, And Relationship Between Price : An Application To World Salmon Markets, American Journal of Agricultural Economics, 31(3) :568-581.

Baharumshah, Ahmad Zubaidi and Muzafar Shah Habibullah 1994. Price Efficiency in Pepper Markets in Malyasia : A Cointegration Analysis, Indian Journal of Agricultural Economics, 49( 2): 205-216

Baulch, B 1997. Transfer Costs, Spatial Arbitrage and Testing for Food Market Integration, American Journal of Agricultural Economics, 49(4):742-751.

Chinn, M.D 1991. Beware of Econometrician Bearing Estimates: Policy Analysis in a 'Unit Root World', Journal of Policy Analysis and Management, 10: 25-34.

Cummings, R. W. Jr 1967. Pricing Efficiency in the Indian Wheat Market, Impex India, New Delhi.

DAM. 1994-2003. Various Issues of Weekly Wholesale Price of Agrl. Product of Selected Markets. Directorate of Agricultural Marketing, Khamarbari, Farmgate, Dhaka.

Fuller, W. A. (1976). Introduction to Statistical Time Series, Willey, New York

Engle, R. F and Granger. C W J. 1987). Cointegration and Error Correction: Representation, Estimation and Testing , Econometrica, 50: 987-1007.

Ghosh, M. 2000. Cointegration Test and Spatial Integration of Rice Markets in India. Indian Journal of Agricultural Ecomics, 55(42) : 213-228.

Gibert, E. H. 1969. Marketing of Staple Foods in Northern Nigeria: A Study of Staple Food
Marketing System Serving Kano City, Ph.D Dissertation, Standford University. Standford, California.

Golleti, F., Ahmed, R. and Farid, N. 1995. "Structural Determinants of Market Integration: The Case of Rice Markets in Bangladesh". The Developing Economics 38(2): 185-202.

Gupta, R. P. 1973. Agricultural Prices in a Backward Economy, National, Delhi.

Gujarati, D. N. 2003. Basic Econometrics. $4^{\text {th }}$ Edition. Mcgraw-Hill, International Edition. New York, U S A.

Illori, A. 1968. Economic Study of Production and Distribution of Staple Food Crops in Western Nigeria, $P h$. D Dissertation, Standford University, Standford, California.

Jones, W. O. 1972. Marketing Staple Food Crops in Tropical Africa, Cornell University Press, Ithaca.

Lele, Uma J. 1967. Foodgrain Marketing in India: Private Performance and Public Policy, Cornel University Press, Ithaca, New York.

Palaskas, T. B. and Harris-White, B. 1993. "Testing Market Integration: New Approaches with Case Material from the West Bengal Food Economy." Journal of Development Studies, 30(1): 1-57.

Ravallion, M. 1986. "Testing Market Integration." American Journal of Agricultural Economics, 68(1): 102-109.

Zanias, G. P. 1993. Testing for Integration in European Community Agricultural Product Markets. Journal of Agricultural Economics, 44(3): 418-427. 